\title{
Research on the cross-border shopping behavior of consumers based on TAM model and perceived risk
}

\author{
Huili Ye \\ School of management, Wuhan University of Technology, Wuhan 430000, China. \\ 790733110@whut.edu.cn
}

Keywords: TAM model, perceived risk, cross-border shopping, consumer behavior

\begin{abstract}
With the popularization of the Internet, shopping online has gradually become a new channel of shopping. Compared with the traditional shopping method, shopping online has the advantage of being free of time and space limitation, low price, complete and rich commodity information, so the online retail industry is developing rapidly. In China, consumption level and consumption concept are constantly improving, and the chain of cross-border ecommerce has been improved gradually, with related policy and principles introduced by country in succession, more and more Chinese consumers are familiar with the cross-border e-commerce. At the same time, cross-border shopping risk is an important restriction factor of consumer behavior, the research on the cross-border shopping behavior of consumers will help the cross-border e-commerce development rapidly. This article presents a new model for studying consumer behavior based on the review of TAM model and related theories, perceived risk theory and consumer shopping behavior, and it will add the cross-border shopping experience, consumer language ability and consumer perception risk into the mode combining with the particularity of the cross-border shopping process, which will improve the explanatory power and predictive power of the model on cross-border shopping behavior of consumers, laying a good theoretical foundation for future empirical research.
\end{abstract}

\section{Introduction}

Cross-border shopping refers to the behavior that consumers browse and select goods on overseas commercial websites, then they submit an electronic order and pay by electronic payment. The goods will be delivered to the consumer directly by international logistics or by transshipment company. China's cross-border e-commerce has entered a phase of full prosperity. According to IiMedia Research, the total transaction size of China's import and export cross-border e-commerce (including retail and B2B) has reached 6.3 trillion in 2016.By 2018, the total transaction size of China's import and export cross-border e-commerce is expected to reach 8.8 trillion yuan. According to IiMedia Research, the number of buyers in the China sea was 0.41 billion in 2016.By 2018, China's market for Chinese buyers is expected to reach 0.74 billion. In 2016, the number of Chinese buyers in the China sea was up 78.3 percent. Since then, the number of Chinese buyers has been slowing down [1].

In the context of globalization, networking and informatization of economic development, it has become a common choice for consumers to choose deeper consumption through the Internet. Therefore, this article analyzed the factors that influence the cross-border shopping behavior of consumers combining the characteristics of cross-border shopping and the perception risk theory, and presented a new model for studying consumer behavior based on the TAM model and perceived risk theory, which will promote the development of cross-border e-commerce industry.

\section{Literature Review}

\subsection{Basic Characteristics of Cross-Border Shopping.}

That principal (individual or enterprise) from different countries trade by the internet or other ways, and make the traditional way of international trade become a new type of network and electronic trade [2]. The current research in this field is only in its infancy. Its main form is that consumer login 
overseas e-commerce sites to choose goods and pay online directly, and then through the international direct mail or transport company to transport the goods to inland.

Qun $\mathrm{Wu}$ argues that the main characteristic of cross-border e-commerce is to be able to make the process of international trade become more complete, such as it can make the information of goods in the international trade transport faster, and it can make the procedure of trade documents processing simple and quick, etc.[3]. Martens and Geomina Turlea through data investigating to consumers, analysis and study the causes of cross-border e-commerce development by the payment system, logistics pattern and cost advantage [4]. Ghorbani et al. studied the influence of e-commerce on the globalization. The study discussed the way to enterprises entering the international market and analyzed the relationship between globalization and e-commerce based on the theory of globalization and the model of globalization [5]. The results show that cross-border e-commerce has big effect on globalization, which even change the nature of the globalization process.

Overall, "cross-border shopping" belongs to e-commerce, but compared with traditional e-commerce, there are two distinct characteristics:

Firstly, due to the overseas e-commerce website, cross-border shopping has a great risk. For example, you need to know relevant international payment tools and prepare ahead of time to complete cross-border online payment. It often takes a long time to send goods from abroad to domestic, during the long haul, there is a risk of goods getting damaged or spoiled, while consumer transnational rights protection is very difficult, which will cause unnecessary loss to consumers, consumers need to be prepared to be unsatisfied after the arrival of goods, what's more ,there is no way to get after-sale service and complain.

Secondly, because of the non-integrated service of consumption mode, consumers are faced with multiple decisions in cross-border shopping. For example, in the traditional online shopping, merchants can provide consumers with perfect ordering system and matching payment and logistics services by self-construction or cooperation with third-party platforms, consumers' decisions simply stay at" what to buy" and "which shop to buy it", therefore, shopping decision is mainly manifested as a single product-service decision-making process. However, in cross-border shopping, the consumer decision-making process is relatively complex, consumers not only have to make product/service decisions, but also have to choose the right payment method, they also should consider to choose logistics smoothly. That is, consumers need to make payment decisions and logistics decisions.

\subsection{Research Review of TAM Model.}

The Technology Acceptance Model, referred to as TAM, mainly comes from TRA. Davis (1989) absorbed the reasonable core of the theory of expectancy theory, self-efficacy theory and other relevant theories, and then proposed the model based on TRA [6]. TAM model believes that the behavior of individuals using information system is caused by behavior Intention, the behavior of individuals using information system was decided by the individual Attitude and perceived usefulness. In the following study, Davis (1993) revised the TAM model and abandoned the behavioral intention, the study suggests that adopting attitude can be used to determine the actual use of the system, and itself affected by perceived usefulness and perceived ease of use, which enhanced the interpretation of TAM model [7].

\subsection{The Composition of Cross-Border Shopping Consumer' Perception Risk.}

Bauer (1960) is the first person to extend perceived risk from psychology to marketing. Bauer believes that consumers cannot accurately predict the results before they buy goods, and the unknown result is risk. He stresses that perceived risk is a subjective experience for consumers. Since then, many scholars began to use Bauer's concept as the basis of his research. Based on some classical literatures, this article collates the definitions of different scholars' representative definition of perceived risk, which is shown in Table1: 
Table 1 The development of perception risk

\begin{tabular}{|c|c|c|}
\hline The researchers & $\begin{array}{c}\text { Year of } \\
\text { study }\end{array}$ & content \\
\hline Bauer & 1960 & $\begin{array}{c}\text { Before buying goods, consumer can't forecast the result } \\
\text { accurately, the unknown result of is the risk. }\end{array}$ \\
\hline Cunningham & 1967 & $\begin{array}{c}\text { Uncertainty and the consequences , the harm of the uncertainty } \\
\text { before consumption and the consequences after consumption }\end{array}$ \\
\hline Derbaix & 1983 & $\begin{array}{c}\text { Perceived risk is actually in the process of product purchase, } \\
\text { consumers could not forest the results, as a result of which } \\
\text { produce the uncertain felling. }\end{array}$ \\
\hline Sweeney & 1999 & $\begin{array}{c}\text { Some study confirmed that perceived risk is closely related to } \\
\text { the perceived value ,so when perceived risk reduced, perceived } \\
\text { value will increase. }\end{array}$ \\
\hline
\end{tabular}

\section{Model Construction}

This article is based on the high risk and multi-decision characteristics of cross-border shopping, and added three variables that may have an impact on the cross-border shopping behavior of consumers based on TAM model.

\subsection{Cross-Border Shopping Experience}

The influence ratio of consumers' network proficiency to shopping behavior of consumers is 0.12[8]. Similarly, consumer overseas online shopping experience has a positive impact on consumer cross-border shopping behavior, when consumers have had the experience of cross-border shopping, he will be familiar with the shopping process of website, product and logistics. It influences consumers' shopping attitude directly through its positive influence on consumers' perceived usefulness and perceived ease of use.

\subsection{Language Ability}

When consumers make cross-border shopping, they browse the web site for non-native site commonly, when cross-border shopping consumer language ability is enough, namely, the product information of the website, logistics information can be accurately identified, and they have no language barrier, consumers are able to select products what they need, which impact on the perceived usefulness and perceived ease of use positively. When consumers do not have certain language skills, they will not be able to identify the information on the website or choose the products, which will affect the process of consumer cross-border shopping. Therefore, it is necessary to use the language ability of consumers as an external influence factor and insert into the TAM model, which can better predict and explain the cross-border shopping behavior of consumers.

\subsection{Perceived Risk}

Perceived risk has an impact on the purchase attitude and purchase behavior of consumers in cross-border shopping, so it is necessary to add the perception risk to TAM model to explain consumer behavior. Many scholars studied the dimensions of the inclusion of perceived risk, the current research on perceived risk is based on six dimensions: financial risk, functional risk, time risk, physical risk, social risk and psychological risks [9]. Stone and Gronhaug (1993) verified the six-dimensional theory, and pointed out that the six-dimensionality explained $88.8 \%$ of the total variance [10]. Based on the situation in the cross-border shopping, this article divides perceived risks into six dimensions: financial risk, functional risk, time risk, physical risk, privacy risk and psychological risk.

Financial risk: the risks arising from the economic losses caused by high freight, or quality problems in the cross-border shopping process.

Functional risk: the risks that the purchased product function cannot meet consumers' anticipated needs. 
Time risk: the language factor of cross-border shopping website will result in this browsing time longer than normal shopping process, which caused a waste of time. At the same time, cross-border shopping logistics time will be long, which also causes waste of time. Or the risks that a product has a quality problem which needs to be replaced.

Physical risk: physical harm to consumers, such as purchases of untested drugs.

Privacy risks: When consumers make cross-border shopping, in shopping, payment, logistics and other processes, you need to fill out personal information on the website, which can lead to information leakage, password theft of bank card, etc. This is the privacy risk mentioned in this article.

Psychological risk: Cross-border shopping has multiple decision-making processes, and the mistakes in decision-making cause the purchase of products to the consumers of emotional injury.

In the process of cross-border shopping, this article intends to analyze the consumer perception risk of cross-border shopping from three parts: the perceived risk in purchasing decision making, perceived risk in payment decision making, perceived risk in logistics decision-making, which is shown in Table2:

Table 2 The development of perception risk

\begin{tabular}{|c|c|}
\hline $\begin{array}{c}\text { The decision making } \\
\text { process }\end{array}$ & Risk dimensions \\
\hline purchasing decision & $\begin{array}{l}\text { Financial risk, functional risk, time risk, physical risk, privacy risk, } \\
\text { psychological risk }\end{array}$ \\
\hline payment decision & Financial risk, physical privacy risk, psychological risk \\
\hline logistics decision & Time risk, privacy risk, psychological risk \\
\hline
\end{tabular}

Therefore, the hypothesis model of this study is shown in Fig. 1:

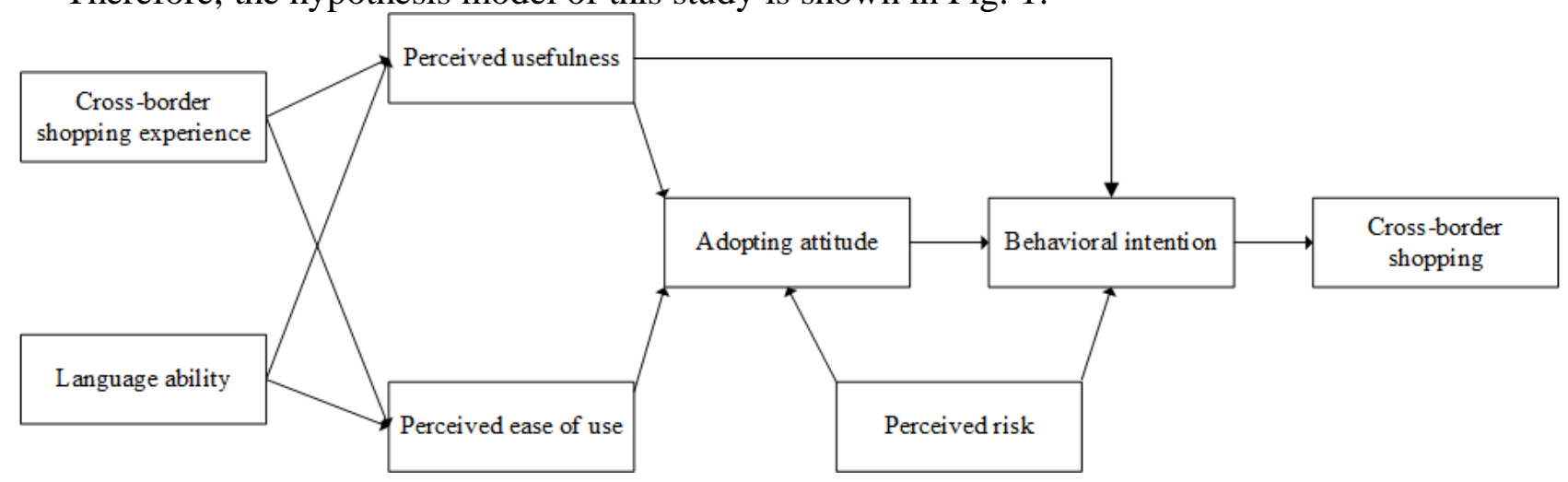

Fig. 1 Conceptual framework

\section{Conclusion}

Cross-border shopping is booming in China. When cross-border shopping, consumer need to browse the foreign website, and to find a transport company, then they need to find a suitable way of payment and so on, which leads to some differences between their behavior and common online shopping behavior. At present, there are few theoretical studies on cross-border shopping, and the discussion about it mainly focuses on the cross-border shopping phenomenon. The research on cross-border shopping from the perspective of behavior is very little. Considering the characteristics of cross-border shopping, three new variables are added to the TAM model to explain the cross-border shopping behavior of consumer better, which provide theoretical support for the globalization of e-commerce and cross-border shopping behavior of consumer.

\section{References}

[1]. Information on: www.199it.com 
[2]. Q. Chen. Research on the development and application of cross-border e-commerce in China. (Master, Kunming university, China 2015) p.6-7

[3]. Q. Wu. Discussing of the development of international e-commerce and China's open economy, Vol. 03 (2009) p. 82-83.

[4]. Ali Ghorbani. Mohammad Bakhtazmay Bonab. Globalization and the Role of E-commerce in Its Expansion. Journal of Basic and Apply Scientific Research, Vol. 03 (2013) p. 78-82.

[5]. N. Terzi. The impact of e-commerce on international trade and employment. Procedia -Social and Behavioral Sciences, Vol. 24 (2011) p. 745-753.

[6]. Davis, F.D. A technology acceptance model for empirically testing new end user information systems: theory and results. (PhD, MIT Sloan School of Management, Cambridge, 1986)

[7]. Davis, F.D. User Acceptance of Information Technology System Characteristics, User Perceptions and Behavioral Impacts[J]. International Journal of Man Machine Studies, Vol. 38 (1993) No. 3, p. 475-487.

[8]. X. Wang, R. Xie, Simulation analysis of the influence factors of shopping network. Journal of Xian transportation university (social science edition) Vol.32 (2012) No.5, p.82-83.

[9]. D. Dong, G. Li, Y. Y. Online shopping consumer perceived risk research about consumer Online shopping. Management Journal, Vol. 1 (2005) p.55-60.

[10]. Stone, R.N. and Gronhaug, K. Perceived Risk: Further Considerations for the Marketing Discipline. European Journal of Marketing, Vol. 27 (1993) No. 3, p. 372-394. 